\title{
Morphophysiological and nutrient uptake characteristics of marigold (Tagetes spp) under different levels of nitrogen fertilization
}

\begin{abstract}
The growth and morpho physiological parameters of marigold plants were evaluated under different nitrogen $(\mathrm{N})$ fertilization during spring and summer of 2014 using pot experiment. A soil with no cultivation background and low level of nitrogen was used for plant cultivation. Nitrogen from urea and at four levels of 0 (control), 50, 100, 200 $\mathrm{mgNkg}^{-1}$ soil was applied and incorporated into the pot soil before and after transplanting. The results showed that marigold overall growth was improved by nitrogen fertilization; however $\mathrm{N}_{50}$ had no significant effect on plant growth compared to control. Nitrogen levels of $\mathrm{N}_{100}$ and $\mathrm{N}_{200}$ were significantly improved plant growth and quality parameters. The plant fresh and dry weight, and flower fresh weight were significantly improved by $\mathrm{N}_{100}$ and $\mathrm{N}_{200}$ treatments, however for most traits there was no significant difference between $\mathrm{N}_{100}$ and $\mathrm{N}_{20} 0$ levels. Leaf $\mathrm{Mg}$ and $\mathrm{Ca}$ concentrations as well as flower longevity on plant were highest in $\mathrm{N}_{100}$ treatment, while $\mathrm{Fe}$ and $\mathrm{Zn}$ were highest in $\mathrm{N}_{200}$ treatment. Therefore considering the negative environmental effects of $\mathrm{N}$ fertilization, it is vise indicated from the results to use moderate $\mathrm{N}$ level for optimum marigold growth and flower quality characteristics.
\end{abstract}

Volume 2 Issue 3 - 2018

\author{
Mohammad Kazem Souri,' Raziyeh \\ Rahmani, ${ }^{2}$ Mohammad Ahmadi, \\ Abdolhossein Rezainejad ${ }^{3}$ \\ 'Department of Horticultural Sciences, Tarbiat Modares \\ University, Iran \\ ${ }^{2}$ Department of Horticultural Sciences, Azad University of Karaj, \\ Iran \\ ${ }^{3}$ Department of Horticulture, University of Lorestan, Iran
}

Correspondence: Mohammad Kazem Souri, Department of Horticultural Sciences, Tarbiat Modares University, Tehran, Iran, Emailmk.souri@modares.ac.ir

Received: August 15, 2017 | Published: May 04, 2018

Keywords: Flower life, nutrients, fertilization, ornamentals, plant nutrition, Tagetes spp

\section{Introduction}

Plant growth performance is influenced by soil fertility, as well as by application of organic and chemical fertilizers. Nitrogen is the major nutrient element required by plants, which present in plant dry matter in highest amount. ${ }^{1,2}$ On the other hand, nitrogen fertilization play important role in plant production and quality parameters of food products. Nitrogen has a vital role in color development of flowers and fruits. However, $\mathrm{N}$ in higher amounts may have negative effects on many quality traits. ${ }^{3,4}$ It was shown that flax genotypes respond positively to $\mathrm{N}$ fertilizer application, in which the highest levels of $\mathrm{N}$ (80kgN ha-1) produced better growth and yield. ${ }^{5}$ Application of rather low levels of nitrogen $(50 \mathrm{kgN}$ ha-1) in Milk thistle plants resulted in highest quality of essential oil. ${ }^{6}$ Nevertheless, high rates of nitrogen can increase the infection rates of diseases and pest damages and may have negative impacts on environment. Nitrogen fertilizers needs precise management regarding the time and dosage application. ${ }^{3,7}$ In ornamentals it is better to apply $\mathrm{N}$ fertilizers in early of plant growth, while later it could have negative effects on plant quality and environment. ${ }^{8}$ Optimum $\mathrm{N}$ fertilization can significantly improve growth and quality of ornamental plants, particularly when soil nitrogen is in low status. ${ }^{9}$ Marigold (Tagetes spp) is an annual and cold intolerance plant from composite family that represents one of the main landscape decorative plants particularly in sides of public green places. Different marigold varieties with various growth habitat and flowering patterns are found on the market. Marigold plants are used commercially for extraction of pigments mainly carotene and xanthophylls for industrial applications. ${ }^{10}$ Marigold has a flowering period from July to October. This indicates that it may have higher nutrient requirements compared to other short-life flowers. It represents also a good candidate for cut flower production. It is possible to improve marigold's flower longevity and quality by optimum nitrogen nutrition. Therefore, this study was done to evaluate the different concentrations of $\mathrm{N}$ on marigold growth and quality including flower life and nutrient elements content.

\section{Material and methods}

This study was conducted during spring and summer of 2014, as pot experiment and in open field conditions. The soil used for cultivation was a 1:3 leaf litter plus 2:3 soil from a non cultivated plot, which the physiochemical properties are presented in Table 1. A local variety of dwarf marigold with orange color was used in this experiment. Seeds were first sown in trays and in a mixture of cocopeat and peatmoss medium (1:1volume). Two weeks later plants were emerged under greenhouse conditions. After 4-6 leaf stage and at the end of April seedlings were transplanted into the main pots and under open air conditions. Three seedlings were transplanted into each pot. Treatments were different concentrations of nitrogen $(\mathrm{N}) 0$, 50,100 and $200 \mathrm{mgNkg}^{-1}$ soil which one third was added and mixed with the soil before transplanting. The remaining urea, representative of exact amount of $\mathrm{N}$ levels, was applied onto the pot soils in two applications (at 6 leaves and before flowering stages). For this purpose, stock solution of $\mathrm{N}$ was prepared and the exact amount of each treatment was added to a given water volume and applied into the soil. The experiment arranged in completely randomized design with 4 treatments and 4 replications. Black plastic pots with volume of nearly $3.5 \mathrm{~kg}$ soil were used as replication. Pots were irrigated once per day based on $80 \%$ of the pot soil water holding capacity. The first flower buds of plants were appeared on July $25^{\text {th }}$ and few days later first flower was completely opened. At harvest and during growth period different plant traits including plant height, number of leaves, number of lateral shoots, chlorophyll index, flower diameter, peduncle length and diameter, flower longevity on plant, leaf area, and flowering date of each treatment were recorded. SPAD index of leaves was recorded by SPAD meter (model 502 Plus, Illinois, USA) by which average of 30 readings for three plants of each pot. Average fresh and dry weight of flowers and whole plant were measured using a precise balance and were calculated before and after drying in oven at $65^{\circ} \mathrm{C}$ for $72 \mathrm{~h}$. Flower diameter and peduncle diameter were measured using Kolis from 3 randomly flowers in the 
middle of main stem from each pot. The plant leaf area was measured using leaf area meter (Model CI 202, Germany). Flower longevity was calculated from the first day of flower opening until the day of collapse. The green fresh leaves of the middle of stem were sampled for determination of nutrient elements. Nitrogen was determined using Kjeldahl method, $\mathrm{K}$ using flame photometer, and $\mathrm{Ca}, \mathrm{Mg}, \mathrm{Fe}$ and $\mathrm{Zn}$ using atomic absorption apparatus. Data were analyzed with SPSS (Version 16), and comparison of means was done at 5\% level using Duncan's multiple range test.

\section{Results}

The results showed that height and leaves number of marigold plants was significantly increased by $\mathrm{N}_{100}$ and $\mathrm{N}_{200}$ levels, while there was no significant difference between $\mathrm{N}_{50}$ and control plants (Table 2). Average plant fresh and dry weight (Table 2) was significantly improved by $\mathrm{N}_{100}$ and $\mathrm{N}_{200}$ but not N50 compared to control plants. Flower diameter was significantly increased by only N200, while it had no significant difference to $\mathrm{N}_{100}$ treatment (Table 2). There was no significant difference among treatments regarding peduncle length; however, peduncle diameter was increased only by $\mathrm{N}_{200}$ treatment (Table 2). Average flower fresh weight was significantly increased by $\mathrm{N}_{100}$ and $\mathrm{N}_{200}$ treatments. Similarly, flower dry weight was highest in $\mathrm{N}_{200}$ which showed no difference to N100 treatment. For most of measured traits control plants showed the lowest records and there was no significant difference between zero control and $\mathrm{N}_{50}$ treatment (Table 2). Leaf SPAD value showed significant increase with higher $\mathrm{N}$ applications $\left(\mathrm{N}_{100}\right.$ and $\left.\mathrm{N}_{200}\right)$, while $\mathrm{N}_{50}$ had no difference with control plants (Figure 1). Average leaf area was significantly increased by $\mathrm{N}$ levels (Figure 1). The highest leaf area was in $\mathrm{N}_{100}$ which showed no significant difference to $\mathrm{N}_{200}$ treatment. The lowest leaf area, similar to other parameters, was in control plants. When plants received $\mathrm{N}_{200}$ they showed significant increase in number of lateral shoots (Figure 1). Measuring flower longevity on plants showed that the longest flowering period was observed in those plants which received $\mathrm{N}_{100}$, and the shortest flowering period was in control plants (Figure 1). Determination of leaf nutrient elements showed that only $\mathrm{N}_{100}$ and $\mathrm{N}_{200}$ treatments resulted in significant increase of leaf $\mathrm{N}$ concentration compared to control plants (Table 3). There was no treatments effect on leaf potassium concentration (Table 3). Leaf magnesium concentration was significantly higher in $\mathrm{N}_{100}$ treatment compared to control, while showed no difference with $\mathrm{N}_{50}$ and $\mathrm{N}_{200}$ treatments (Table 3). Leaf calcium concentration was significantly increased only by $\mathrm{N}_{100}$, while there was no significant difference among $\mathrm{N}_{200}, \mathrm{~N}_{50}$ and control treatments (Table 3). Leaf iron and zinc concentrations were significantly increased in $\mathrm{N}_{200}$, while there was no significant difference between $\mathrm{N}_{100}$ and $\mathrm{N}_{50}$ with control plants (Table 3).

Table I Physiochemical properties of the soil used in the experiment

\begin{tabular}{llllllllll}
\hline Soil texture & Sand (\%) & Silt (\%) & Clay (\%) & EC (ds/m) & $\mathbf{p H}$ & Organic carbon (\%) & $\mathbf{N}(\%)$ & $\mathbf{P}(\mathbf{m g} / \mathbf{k g})$ & $\mathbf{K}(\mathbf{m g} / \mathbf{k g})$ \\
\hline Silty-loamy & 30 & 46 & 24 & 0.915 & 7.17 & 0.02 & 0.096 & 15.2 & 256
\end{tabular}

Table 2 Comparison of means for some growth traits of marigold plants under different nitrogen levels. The data are average of four replicates \pm SD. Comparison of means was done at $5 \%$ of Duncan multiple test

\begin{tabular}{|c|c|c|c|c|c|c|c|c|c|}
\hline $\mathrm{N}$ levels & $\begin{array}{l}\text { Height } \\
(\mathrm{cm})\end{array}$ & $\begin{array}{l}\text { Leaf } \\
\text { Number }\end{array}$ & $\begin{array}{l}\text { Plant FW } \\
\text { (g) }\end{array}$ & $\begin{array}{l}\text { Plant DW } \\
\text { (g) }\end{array}$ & $\begin{array}{l}\text { Flower } \\
\text { diameter (mm) }\end{array}$ & $\begin{array}{l}\text { Peduncle } \\
\text { length (mm) }\end{array}$ & $\begin{array}{l}\text { Peduncle } \\
\text { diameter }(\mathrm{mm})\end{array}$ & $\begin{array}{l}\text { Flower FW } \\
\text { (g) }\end{array}$ & $\begin{array}{l}\text { Flower DW } \\
\text { (g) }\end{array}$ \\
\hline Control & $11.8 \pm 0.9 c$ & $23.8 \pm 2.2 \mathrm{c}$ & $24 \pm 1.5 b$ & $2.5 \pm 0.2 b$ & $36.8 \pm 1.0 \mathrm{~b}$ & $4.4 \pm 0.3 a$ & $6.4 \pm 0.5 b$ & $5.9 \pm 0.4 b$ & $0.93 \pm 0.06 b$ \\
\hline N $50^{*}$ & $12 \pm 1.3 c$ & $26.3 \pm 2.8 b c$ & $27 \pm 3.7 b$ & $2.5 \pm 0.1 b$ & $36.9 \pm 0.8 b$ & $4.5 \pm 0.2 \mathrm{a}$ & $6.5 \pm 0.7 b$ & $6 \pm 0.4 b$ & $0.94 \pm 0.04 b$ \\
\hline N 100 & $14.4 \pm 0.8 b$ & $28 \pm 2.5 a b$ & $38 \pm 5.3 a$ & $2.9 \pm 0.3 a$ & $37 \pm 1.4 \mathrm{ab}$ & $4.5 \pm 0.3 a$ & $6.6 \pm 0.5 b$ & $7 \pm 0.6 a$ & $0.96 \pm 0.01 \mathrm{ab}$ \\
\hline N 200 & $16.4 \pm 1.6 a$ & $33 \pm 3.4 a$ & $44 \pm 6.4 a$ & $3 \pm 0.1 a$ & $39.5 \pm 1.3 a$ & $4.8 \pm 0.4 a$ & $7.3 \pm 0.3 a$ & $7.1 \pm 0.6 a$ & $0.98 \pm 0.02 a$ \\
\hline
\end{tabular}

*N50, N1 00 and N200 represent the N levels of 50, 100 and 200mg Nkg-I soil.

Table 3 Comparison of means for marigold leaf nutrients concentration. The data are average of four replicates \pm SD. Comparison of means was done at $5 \%$ of Duncan multiple test.

\begin{tabular}{lllllll}
\hline N levels & N (\%) & K (\%) & Mg (\%) & Ca (\%) & Fe (mg kg-I DW) & Zn (mg kg-I DW) \\
\hline Control & $1.8 \pm 0.2 b$ & $2.2 \pm 0.26 \mathrm{a}$ & $0.90 \pm 0.05 \mathrm{~b}$ & $2.2 \pm 0.23 \mathrm{~b}$ & $59.4 \pm 6.1 \mathrm{~b}$ & $44.5 \pm 6.0 \mathrm{~b}$ \\
$\mathrm{~N} 50^{*}$ & $2 \pm 0.18 \mathrm{~b}$ & $2.3 \pm 0.18 \mathrm{a}$ & $0.92 \pm 0.10 \mathrm{ab}$ & $2.3 \pm 0.28 \mathrm{~b}$ & $59 \pm 5.1 \mathrm{~b}$ & $45.6 \pm 3.8 \mathrm{~b}$ \\
$\mathrm{~N} 100$ & $2.5 \pm 0.2 \mathrm{la}$ & $2.2 \pm 0.24 \mathrm{a}$ & $1.0 \pm 0.12 \mathrm{a}$ & $2.9 \pm 0.40 \mathrm{a}$ & $61.1 \pm 5.5 \mathrm{~b}$ & $45.7 \pm 7.4 \mathrm{~b}$ \\
$\mathrm{~N} 200$ & $2.8 \pm 0.27 \mathrm{a}$ & $2.3 \pm 0.30 \mathrm{a}$ & $0.93 \pm 0.04 \mathrm{ab}$ & $2.4 \pm 0.17 \mathrm{ab}$ & $70.1 \pm 5.2 \mathrm{a}$ & $50.1 \pm 10.9 \mathrm{a}$
\end{tabular}

*N50, NI00 and N200 represent the N levels of 50, 100 and 200mg Nkg-I soil. 

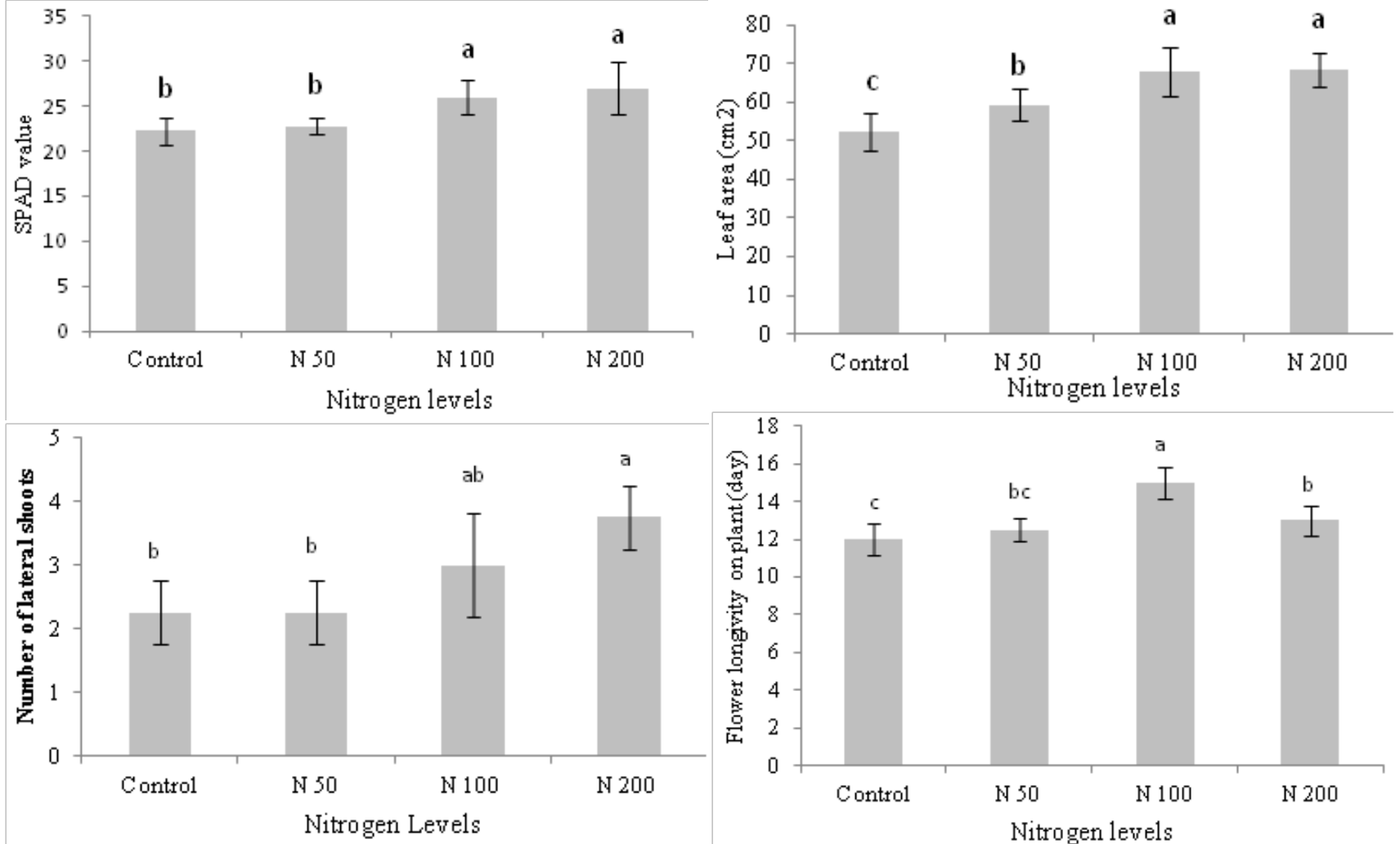

Figure I SPAD value, leaf area, number of lateral shoots and flower longevity on plants of marigold affected by various nitrogen levels. The $\mathrm{N}$ levels indicate 0 , 50,100 and $200 \mathrm{mg} \mathrm{kg-I}$ soil of pure N. comparison of means were done at $5 \%$ of Duncan test.

\section{Discussion}

The soil which was used in present study had rather low level of nitrogen. Other minerals however were in acceptable range. Plant growth parameters including vegetative and flowering quality parameters were improved by nitrogen levels of $\mathrm{N}_{100}$ and $\mathrm{N}_{200}$; while for most parameters there was no significant difference between $\mathrm{N}_{50}$ and control. In addition, for most traits there was no significant difference between $\mathrm{N}_{100}$ and $\mathrm{N}_{200}$ levels. However, leaf $\mathrm{Mg}$ and $\mathrm{Ca}$ concentrations as well as flower longevity on plant were highest in $\mathrm{N}_{100}$ treatment, and leaf $\mathrm{Fe}$ and $\mathrm{Zn}$ were highest at $\mathrm{N}_{200}$ treatment. The no response of plants to $\mathrm{N}_{50}$ can be probably due to ammonium fixation of clay minerals of soil. ${ }^{11}$ Improvement in plant vegetative and quality parameters of other ornamental flowers by application of nitrogen fertilizers has been also reported., ${ }^{9} 12-14$ The similar results have been also reported in other studies with food crops. ${ }^{4-6}$ Nitrogen is the most effective essential nutrient elements in plant vegetative growth and it is the main limiting factor for plant production in agro ecosystems. ${ }^{2}$ It plays role in many physiological processes including photosynthesis and biosynthesis of amino acids and protein, various enzymes, phytohormones and many secondary metabolites. ${ }^{1,3,15}$ The amount and form of nitrogen fertilization has significant effect on plant growth and metabolism. ${ }^{2,16}$ Nitrogen is the most effective nutrients in increasing number of lateral shoots, leaf area and chlorophyll content of leaves ${ }^{1,2,17}$ however, various plants may respond different concerning these traits.

Flower longevity on plant was significantly highest in $\mathrm{N}_{100}$, despite it was also increased by $\mathrm{N}_{200}$ compared to control. Considering the high cost of nitrogen fertilizer application and their negative environmental effects, it is vise to use less to medium amount of $\mathrm{N}$ fertilizers when there is no significant reduction in yield and quality. ${ }^{6,7}$ Determination of leaf nutrient concentrations revealed that $\mathrm{N}_{100}$ and $\mathrm{N}_{200}$ resulted in higher nutrient status of leaves, however for most nutrients their highest content was obtained from $\mathrm{N}_{100}$ treatment (Table 3). Among the nutrient elements, nitrogen is well known that different aspects of its application can significantly influence the uptake and translocation of other nutrients. ${ }^{17}$ Nitrogen has a general positive interaction with most of nutrient elements, ${ }^{2,4,7}$ and generally increasing $\mathrm{N}$ from a deficiency level can improve nutrients uptake and their tissue amounts of $\mathrm{P}, \mathrm{Ca}, \mathrm{K}, \mathrm{Mg}, \mathrm{Fe}, \mathrm{Zn}^{4,17}$ On the other hand increasing $\mathrm{N}$ beyond sufficiency levels can also negatively influence plant growth and quality. ${ }^{16}$ Nitrogen fertilization has generally significant influence on many biochemical quality parameters of plants including the content of various secondary metabolites such as vitamins. ${ }^{18}$ There has been also significant increase in antioxidant capacity of plants due to $\mathrm{N}$ fertilizer application. ${ }^{19}$ Nevertheless, the amount of $\mathrm{N}$ fertilization for optimum yield and quality must regarded the environmental standards.

\section{Conclusion}

In present study, the vegetative growth and flowering of marigold plants were affected by application of nitrogen levels of $\mathrm{N}_{100}$ and $\mathrm{N}_{200}$, but not $\mathrm{N}_{50} \mathrm{mgkg}^{-1}$. Despite there was no significant difference between $\mathrm{N}_{100}$ and $\mathrm{N}_{200}$, but for most growth and quality traits, $\mathrm{N}_{100}$ had the highest values including highest nutrient contents and longer life of flowers on plants. Nitrogen is one of the most important essential elements for plant growth and development, and it is also the 
main limiting factor for plant growth, so, it has a distinct impact on vegetative growth and quality production of plants. Nevertheless, due to its harmful effects on environment, it is better to use less or medium level of nitrogen. Nitrogen as the most important essential elements for plant growth and development has a distinct impact on quantity and quality production in agriculture.

\section{Acknowledgments}

None.

\section{Conflict of interest}

The authors declare there is no conflict of interest.

\section{References}

1. Marschner H. Mineral nutrition of higher plants. $2^{\text {nd }}$ ed. England:Academic press; 1995.

2. Souri MK, Roemheld V. Split daily application of ammonium cannot ameliorate ammonium toxicity in tomato plants. Hort Environ Biotechnol. 2009;50:384-391

3. Parasad R. Fertilizer urea, food security, health and the environment. Curr Sci. 1998;75(7):677-683.

4. Biesiada A, Kuś A. The Effect of nitrogen fertilization and irrigation on yielding and nutritional status of sweet basil (Ocimum Basilicum L.). Acta Sci Pol Hortorum Cultus. 2010;9(2):3-12.

5. Homayouni G, Souri MK, Zarein M. Effects of Zinc and Nitrogen on Yield Components of Five Flax Genotypes. Global J Sci Front Res Chem. 2013;13(5):20-24.

6. Estaji A, Souri MK, Omidbaigi R. Evaluation of different levels of nitrogen and flower pruning on milk thistle (Silybum marianum L.) yield and fatty acids. J Med Spi Plant. 2011;4:170-175.

7. Fageria NK, Baligar. Enhancing nitrogen use efficiency in crop plants. Adv Agron. 2005;88:97-185.
8. Kania A, Szabo B, Souri MK, et al. Functional characterization of the stabilized organic turf grass fertilizer Marathon. Rasen Turf Gazon. 2007;1:192-195.

9. Joiner JN, Poole RT, Conover CA. Nutrition and fertilization of ornamental greenhouse crops. Horticultural Reviews. 1983;5:317-403.

10. Hooks CR, Wang KH, Ploeg A, et al. Using marigold (Tagetes spp.) as a cover crop to protect crops from plant-parasitic nematodes. Applied Soil Eco. 2010;46(3):307-320.

11. Miller AJ, Cramer MD. Root nitrogen acquisition and assimilation. Plant and Soil. 2005;274(1-2):1-36.

12. Ter Hell B, Hendriks L. The influence of nitrogen nutrition on keeping quality of pot plants. VI International Symposium on Postharvest Physiology of Ornamental Plants. 1995;405(17):138-147.

13. Gadagi RS, Krishnaraj PU, Kulkarni JH, et al. The effect of combined Azospirillum inoculation and nitrogen fertilizer on plant growth promotion and yield response of the blanket flower Gaillardia pulchella. Scientia Horticulturae. 2004;100(1-4):323-332.

14. Hershey DR, Paul JL. Leaching-losses of nitrogen from pot chrysanthemums with controlled-release or liquid fertilization. Scientia Horticulturae. 1982;17(2):145-152.

15. Sinclair TR, Horie T. Leaf nitrogen, photosynthesis, and crop radiation use efficiency: a review. Crop science. 1989;29:90-98.

16. Heeb A, Lundegårdh $\mathrm{B}$, Ericsson $\mathrm{T}$, et al. Nitrogen form affects yield and taste of tomatoes. J Sci Food Agri. 2005;85(8):1405-1414.

17. Souri MK. Aminochelate fertilizers: the new approach to the old problem: a review. Open Agri. 2016;1(1):118-123.

18. Mozafar A. Nitrogen fertilizers and the amount of vitamins in plants: A review. J plant nutri. 1993;16(12):2479-2506.

19. Mareczek A, Leja M. Effect of urea foliar application on antioxidative properties of lettuce and broccoli. Sodininkyste ir Daržininkysté. 2005;24(3):235-241. 